\title{
Assessing use, diversity and local conservation priorities of woody species within agroforestry systems along Ouémé catchment in Benin (West Africa)
}

Bruno Enagnon Lokonon ${ }^{1,2^{*}}$, Essomanda Tchandao Mangamana ${ }^{2}$, Romain Glèlè Kakaï ${ }^{2}$ and Brice Sinsin ${ }^{1}$

\begin{abstract}
Ouémé catchment experiences increasing degradation of its natural resources due to anthropogenic pressure. Consequently, most of the agroforestry species as well as the cultural and Indigenous knowledge related to them are facing a very high risk of extinction. The present research aimed to assess the biodiversity of the useful woody species in this area and their cultural importance and then prioritize these woody species for conservation purpose. An ethnobotanical survey was carried out among 411 randomly selected households followed by an ecological survey conducted in 69 random plots of 0.15 ha. Ecological and ethnobotanical parameters were calculated and then analyzed. To determine the local priorities species for conservation, a local conservation priority index (LCPI) was computed for each species. The high value of LCPI for a given species indicates the need for a greater level of attention for conservation and management. Forty-five useful woody species belonging to 21 families dominated by Leguminosae $(24.44 \%)$ and Anacardiaceae $(8.88 \%)$ were reported. The forty-five species were categorized into six use categories by the informants: food, medicinal, construction, fuel, veterinary and technology. The most useful species were Elaeis guineensis $(U V=0.24)$, followed by Parkia biglobosa $(U V=0.19)$ and Vitellaria paradoxa $(U V=0.18)$. The prioritization method yielded top ten ranked species: Parkia biglobosa, Pterocarpus erinaceus, Adansonia digitata, Milicia excelsa, Irvingia gabonensis, Vitex doniana, Prosopis africana, Diospyros mespiliformis, Afzelia africana and Vitellaria paradoxa. With the aim of establishing the sustainable management in the catchment, we suggest that more attention be paid to the aforementioned species as part of rehabilitation activities.
\end{abstract}

Keywords: Conservation priorities, Biodiversity, Local knowledge, Useful plants, Ouémé catchment.

\footnotetext{
1Laboratory of Applied Ecology, Faculty of Agronomic Sciences, University of Abomey-Calavi, 05 BP 1752 Cotonou, Benin 2Laboratory of Biomathematics and Forest Estimations, University of Abomey-Calavi, 03 B.P. 2819 Cotonou, Benin * Corresponding author. $\square$ E-mail address: BEL (brunolokonon@gmail.com), ETM (tchanesso@yahoo.fr), RGK (gleleromain@yahoo.fr), BS (bsinsin@gmail.com)
} 


\section{INTRODUCTION}

Traditional agroforestry system is a long evolutionary process in which an association between natural elements such as trees and shrubs share the same stands with crops and sometimes with households (Kyndt et al. 2009). Many studies have revealed the social, economic, and ecological importance of the traditional agroforestry systems (Eloy 2008; Nouaïm et al. 2007). The natural resources involved in the agroforestry systems play a very important role in the livelihoods of rural communities (Assogbadjo et al. 2012). They serve as an alternative to staple food during the periods of food deficit (Vodouhê et al. 2009) and are also a source of income for many rural communities (Fandohan et al. 2010). Assogbadjo et al. (2012) argued that it is important to know the reasons that support the integration of these natural resources in agroforestry systems, their diversity and local communities preferences about their uses. This information is very useful to enhance agroforestry's capacity to fulfill its potential and to secure long-term availability.

Among the agroforestry systems components, the woody plant species (trees and shrubs) represent a significant component. Indeed, they have multiple functions (Cuni Sanchez et al. 2010). Local people depend on them mainly for plant medicine, food, forage, construction of dwellings, making household implements, beds and sleeping mats, and for firewood and shade (Asuzu and Harvey 2003; De Smedt et al. 2011; Omafuvbe et al. 2004; Vodouhê et al. 2009).

Despite their importance, little is known in Benin on wild woody plants diversity in agroforestry systems and local communities' knowledge about the integrated species (Assogbadjo et al. 2012). Moreover, pressures from multiple sources including population growth and recurrent drought are resulting in the loss of trees or regeneration inhibiting, posing serious threats to the development of agroforestry systems (Sina 2006). Therefore, it is necessary to inventory the diversity of these species and establish priorities for conservation (Kell et al. 2008). Prioritization for conservation can be undertaken at different levels: species, ecosystem, etc. (Brehm et al. 2010). A method of prioritizing at species level is preferable because it allows conservationists to know which taxa should be primarily targeted for conservation, which are not priorities, and which have insufficient information to know whether they are priorities for conservation or not (Brehm et al. 2010).

Like in the whole Benin, Ouémé catchment, which represents an important reserve of biodiversity, is experiencing anthropogenic pressures on its agroforestry system components (Hiepe and Diekkrüger 2006). Fruit productions of the trees are badly reaped hypothecating regeneration (Eyog Matig et al. 2002) as well as timber use involving the death of plants (Tunholi et al. 2013). Consequently, most of the useful woody species as well as the indigenous knowledge related to them are facing a risk of extinction (Assogbadjo et al. 2012). In contrast, no research has studied the traditional values that support the preservation of certain useful woody species in the agroforestry systems by local communities of Ouémé catchment area. A number of studies have been carried out in this area (e.g. Hiepe and Diekkrüger 2006; Hiepe 2008; Sintondji 2005), however, they mainly focused on water resources management and climate change.

Since the Convention for Biological Diversity has firmly acknowledged the role of 
indigenous knowledge in biodiversity conservation, ethnobotanical researches have further developed great interest (Sop et al. 2012). Use of indigenous knowledge is becoming a quick and reliable method of acquiring information since no sophisticated and complex tools are required (Lykke 2000). Indeed, livelihood of local people is often highly associated with natural resources in their surrounding and this gives them a deep knowledge. Preview research studying farmers' strategies for adapting to climate vulnerability in Ouémé catchment area showed that local people have developed a remarkable ability to adapt to environment changes, and in some cases have turned threats into opportunities (Kpadonou et al. 2012).

Knowing the increasing focus on the role of agroforestry systems to help maintain a high level of local biodiversity outside protected areas (Assogbadjo et al. 2012; Oke and Jamala 2013), we made assumption that the local people of Ouémé catchment carry on the maintain of biodiversity of useful woody species in their farms despite the increased threat. We also made assumption that the local people use the woody species for multiple purposes and have accumulated Indigenous knowledge related to them. Moreover, knowing that all conservation has a cost, it is important to proceed by prioritization and select the species that conservation may be a priority regarding their cultural importance and ecological availability in Ouémé catchment environment. We therefore made supposition that the species that are the most used are the most priorities for conservation. The objectives of this paper were to 1) assess traditional agroforestry richness in useful woody species, 2) identify and describe the use categories and the use values of the woody species and link them to the ecological parameters, 3) evaluate their local conservation priorities through the use of a constructed conservation priority index.

\section{MATERIAL AND METHODS}

\section{Study area}

The Ouémé catchment $\left(49,256 \mathrm{~km}^{2}\right)$ is located from central to southern regions of the Republic of Benin between 6.8 and $10.2^{\circ}$ North latitude and between 1.5 and $3.5^{\circ}$ East longitude (Figure 1). In the central part it is characterized by tropical climate with mean annual rainfall ranging from 900 to $1000 \mathrm{~mm}$ and in southern part by subequatorial climate with a mean annual rainfall of $1200 \mathrm{~mm}$ (Assogbadjo et al. 2006). The landscape is characterized by forest $(21.74 \%$ of the total area), savannah $(40.76 \%)$, mosaic with agriculture $(34.17 \%)$ (Keyzer et al. 2007). About 12,000 households inhabit the catchment, $60 \%$ of them is employed in agriculture (Keyzer et al. 2007). The most important socio economic groups are Mahi, Goun, Fon, Peulh, Dendi, Bariba and Nagot.The economic activities are mainly agriculture (crop production), breeding, trade, and transport. The agricultural production is dominated by food and cash crops. It constitutes the principal source of income for the major part of the population. The typical form of agricultural land use is the parkland agroforestry system, which involves intercropping of agricultural crops under scattered mature trees in farms. Useful trees are retained by farmers in the agroforestry systems due to their variety of non-timber uses such as food and medicinal use (Teklehaimanot 2004). Maize (Zea mays), yam (Dioscorea spp.) and cassava (Manihot esculenta) are the major food crops. 


\section{Sampling and data collection}

We conducted semi-structured interviews with the household using a questionnaire. In total, 10 localities have been sampled from the 47 districts of the catchment due to their implication in agroforestry practices. In each of the 10 sampled localities from the catchment (Figure 1), the number $\mathrm{n}$ of the surveyed.

Individuals was estimated using the normal approximation of the binomial distribution (Dagnelie 1998).

$$
n=U^{2} 1-\alpha / 2\left[P(1-P) / d^{2}\right]
$$

where:

- $\mathrm{n}$ is the total number of surveyed people within a locality;

- U1- $\alpha / 2=1.96$ for $\alpha=0.05$;

- $P$ is the estimated proportion of informants that have at least two woody species involved in the agroforestry systems;

- $d$ is the expected error margin of any parameter to be estimated from the survey and is considered as $5 \%$.

To compute the sample size $\mathrm{n}$, a brief survey on 60 interviewees (Dagnelie 1998) was done in the catchment. The number 60 is referred to approximation of the Normal distribution (from the Binomial distribution). Indeed, a good approximation of the Normal distribution can be obtained (from a sample that follow the Binomial distribution) when the sample size is at least 30 . The proportion $P$ of positive answers was $P=58 / 60, P \approx 0.97$.

By computing using the formula the number $\mathrm{n}$ of surveyed randomly sampled in each locality, the total number of respondants considered throught the Ouémé catchment area was 411, with 91 women
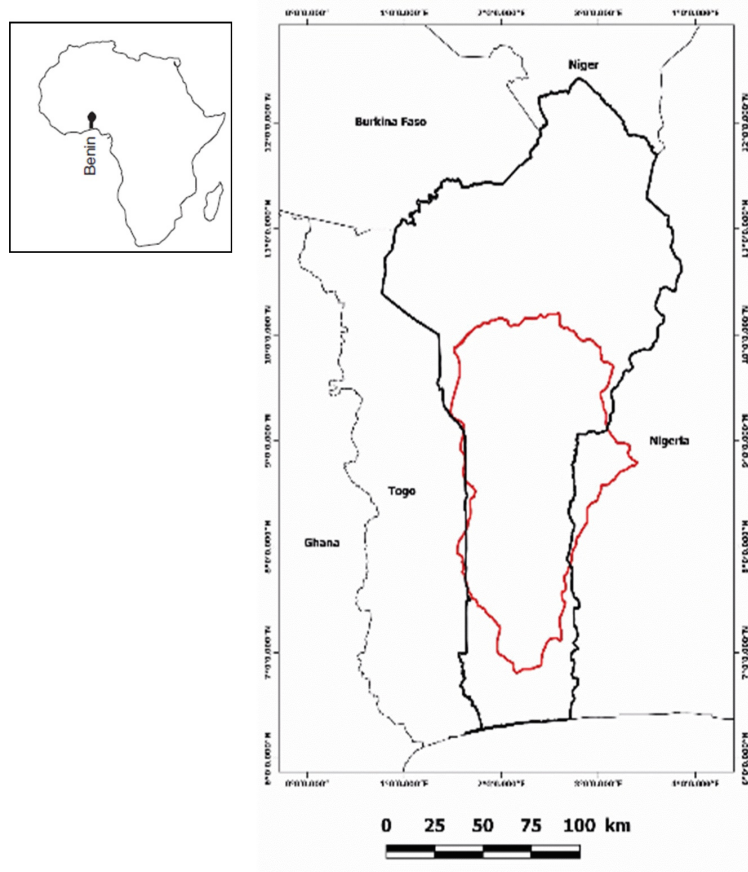

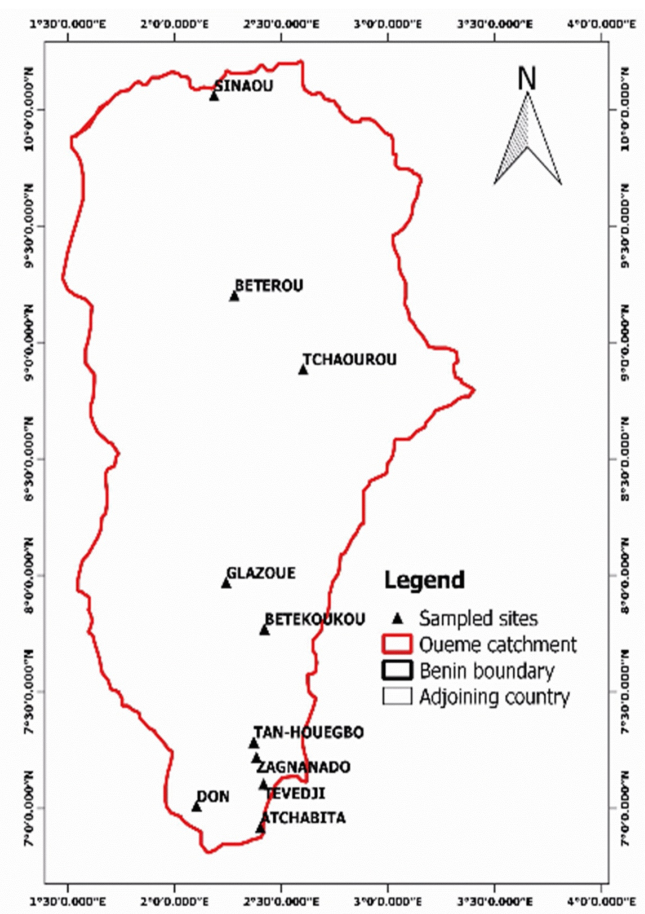

Figure 1. Location of the surveyed localities within the Ouémé catchment in Benin (West Africa). 
and 320 men. The ages of the participants ranged from 25 to 85 years.

In each household, the household head or in his absence, elderly individuals willing to participate in the study were interviewed. The interviewers talked to each participant and introduced the objective of the study. The participant gave his consent and the interview took place. Before executing the intensive household survey, the questionnaire was pre-tested and subsequently improved. The interview was conducted entirely in the informants' local languages with translation when necessary. The main emphasis was on the identification of useful woody plant species integrated in traditional agroforestry systems. For each listed species, the participant gave information on the uses that made that species important to him/her, the harvested organs from the tree and their preference for this species. During the interviews, participants were asked to list the species using their local names. The species were later identified taxonomically using the Analytic Flora of Benin (Akoègninou et al. 2006). The informants were asked to cite species from the agroforestry systems that they actually use and not those of which they merely know (Stagegaard et al. 2002). Ecological data were obtained through inventory carried out in 69 randomly allocated plots, each measuring $30 \times 50 \mathrm{~m}$. From each locality, six or seven plots were established within the agroforestry systems belonging to the surveyed householders. Within each plot, all useful woody species with diameter $\geq 3 \mathrm{~cm}$ and height $\geq 1 \mathrm{~m}$ were recorded (Trindade et al. 2015) and their diameter at breast height were measured. Plant materials were collected for identification, prepared as herbarium samples. Identification has been done using the Analytic Flora Benin (Akoègninou et al.
2006), a field guide (Arbonnier 2000) or by consulting specialists at the National Herbarium of Benin. Moreover, the PROTA4U (http://www.prota4u.org/) and IUCN sites as well as national documents have been consulted to obtain information related to the status of the species.

\section{Data analysis}

The following ecological parameters were calculated: Species richness (S), relative density (RD), relative frequency (RF), relative dominance (RDo) and Importance Value (IV) and were then analyzed following Araújo and Ferraz (2014).

$$
S=\text { Total number of the species }
$$

$$
\begin{gathered}
R D=\frac{\text { Number of individuals of the species } \times 100}{\text { Number of individuals of all the species }} \\
R F=\frac{\text { Number of occurrence of the species } \times 100}{\text { Number of occurrence of all the species }} \\
R D o=\frac{\text { Total basal area of the species } x 100}{\text { Total basal area of all the species }} \\
\mathrm{IV}=\mathrm{RD}+\mathrm{RF}+\mathrm{RDo}
\end{gathered}
$$

The plants mentioned in the surveys were grouped into categories of use commonly adopted in ethnobotanical studies and the definition of the categories of use was based on the considerations of Lucena et al. (2008). The relative importance of each plant was quantified by computing the use value (UV) for each species, botanical family and use category using the indices proposed by Phillips and Gentry (1993), as modified by Rossato et al. (1999) and Galeano (2000): 


$$
\begin{aligned}
& \text { UVs }=\sum{\mathrm{Us} \cdot n \mathrm{i}^{-1}}^{-} \\
& \mathrm{UVc}=\sum \mathrm{UVsc} \\
& \mathrm{UVsc}=\sum \mathrm{Uscni}^{-1}
\end{aligned}
$$

(7) and the measured parameters. The $R$ package FactoMineR (Husson et al. 2014)

(8) has been used to implement the PCA. The data have been standardized by using the argument "scale.unit=TRUE".

To determine the local priorities species

where UVs is the use value for each species, Us is the number of uses mentioned for each species, ni is the total number of informants, UVc is the UV of a category, UVsc is the UV of each species in the category, and Usc is the number of uses for each species listed in the category. The Kruskal Wallis test was used to compare UV among the use categories due to nonnormality of the data. Principal Component Analysis (PCA) was performed to describe the link between the useful woody species for conservation, the local conservation priority index (LCPI) was computed. The LCPI used here is inspired from Albuquerque et al. (2009) and considers the following parameters: citation richness (CR), Frequency (F), Local Use (LU), Relative Density (RD) of the species in the agroforestry systems and the Harvesting risk score $(\mathrm{H})$ (Table 1).

In order to calculate $\mathrm{CR}$, the numbers of use categories for each species were given scores as noted in the table 1. Only the categories that implied a harvesting demand

Table 1. Parameters and scores used to calculate the priority index. Modified from Albuquerque et al. (2009).

\begin{tabular}{l|c}
\hline Parameters & Scores \\
\hline Citation Richness (CR) & \\
\hline Two (02) points are summed for each use categories reported & $2-12$ \\
\hline Frequency (F) & \\
\hline High (frequency of the species in the farms $\geq 60 \%$ ) & 1 \\
\hline $\begin{array}{l}\text { Moderate (frequency of the species in the farms } \geq 20 \% \text { and } \\
<60 \% \text { ) }\end{array}$ & 4 \\
\hline Low (frequency of the species in the farms $<20 \%$ ) & 7 \\
\hline Weak (not encountered in the farms) & 10 \\
\hline Local Use (LU) & 10 \\
\hline High (cited by $>20 \%$ of the local informants) & 7 \\
\hline Moderately high (cited by 10 to $20 \%$ of the local informants) & 4 \\
\hline Moderately low (cited by $<10 \%$ of the local informants) & 10 \\
\hline Relative Density (RD) & 7 \\
\hline Not encountered-very low (0-1) & 4 \\
\hline Low (1<3.5) & 1 \\
\hline Medium (3.5<7) & 10 \\
\hline High ( $\geq 7$ ) & \\
\hline Harvesting risk score & 7 \\
\hline $\begin{array}{l}\text { Harvesting results in over-exploitation of roots, bark or removal } \\
\text { of the plant }\end{array}$ & 1 \\
\hline $\begin{array}{l}\text { Harvesting affects perennial structures such as the bark and } \\
\text { roots. Harvesting does not cause the death of the plant }\end{array}$ & 7 \\
\hline $\begin{array}{l}\text { Harvesting affects permanent aerial portions of the plants } \\
\text { (leaves), which are removed }\end{array}$ & 4 \\
\hline $\begin{array}{l}\text { Harvesting affects transitory aerial portions of the plants (flowers } \\
\text { and fruits), which are removed }\end{array}$ & 1 \\
\hline
\end{tabular}


for natural products were included in the analysis (Albuquerque et al. 2009). The frequency $(F)$ was estimated by dividing the number of plots in which the species occurred by the total number of plots studied. The Local Use (LU) is related to the proportion of respondents that cited each species as presented in the table 1. The RD was calculated following the equation (2) above. The Harvesting risk score $(H)$ is based on the biological consequences of harvesting and depends on the plants part removed (Table 1). The LCPI was calculated for each of the species following the equation (10). The maximum value that a species could attain was 52.

$$
\mathrm{LCPI}=\mathrm{CR}+\mathrm{F}+\mathrm{LU}+\mathrm{RD}+\mathrm{H}
$$

\section{RESULTS}

\section{Diversity of the useful woody species}

A total of 64 useful woody species (Figure 2 ) were cited by the respondents during the interviews. These species belong to 25 botanical families. Moreover, 54 useful woody species belonging to 26 families were encountered in the sampled plots during the ecological survey (Figure 3 ). Since there is a difference between the number of the species cited by the informants and the one obtained in the plots, we focused our analysis on the 45 species which were present in both surveys. The 45 species were distributed into 21 families. The most represented family was Leguminosae (11 species), followed respectively by Anacardiaceae (4 species), Bombacaceae, Moraceae, Verbenaceae (3 species each), Combretaceae, Euphorbiaceae, Meliaceae,
Myrtaceae and Rubiaceae (2 species each). Eleven families were represented by only one species. The species most cited by the informants were Mangifera indica, Tectona grandis, Elaeis guineensis, Anarcadium occidentale, Pterocarpus erinaceus, Parkia biglobosa, Vitellaria paradoxa, Anogeissus leiocarpa and Ceiba pentandra. In total, 1647 individuals were recorded from the plots. The species most encountered in the plots were Tectona grandis, Afzelia Africana, Pterocarpus erinaceus, Anarcadium occidentale, Azadirachta indica, Elaeis guineensis, Mangifera indica, Parkia biglobosa, Vitellaria paradoxa, Daniellia oliveri and Anogeissus leiocarpa.

\section{Ethnobotanical and ecological parameters}

The figure 4 shows the importance values (IV) of the botanical families while the figure 5 presents the use values (UV). Families with highest IV were Leguminosae (62.64 $\%)$, Arecaceae (52.18\%), Anacardiaceae $(51.57 \%)$ and Verbenaceae (37.67 \%). Families with highest UV and demonstrating the largest use-versatility were Leguminosae (0.85), Anacardiaceae (0.42), Verbenaceae (0.27) and Arecaceae (0.24). The Leguminosae was the most important family in terms of IV and UV.

The 45 species were categorized into six use categories by the informants: food, medicinal, construction, fuel, veterinary and technology. Among these species, 93.33\% were used for medicine, $88.06 \%$ for fuel, $80.6 \%$ for construction, $79.10 \%$ for technology, $62.69 \%$ for food and $25.37 \%$ for veterinary. Regarding the UV of the categories, medicinal was the highest $(U V=1.42)$, which differed significantly from the other categories $(\mathrm{H}=105.44 ; \mathrm{P}=0.000)$, followed by fuel $(U V=0.77)$ and technology $(U V=0.73)$. The part of the plant most often used was leaf $(26.50 \%)$ followed by bark 


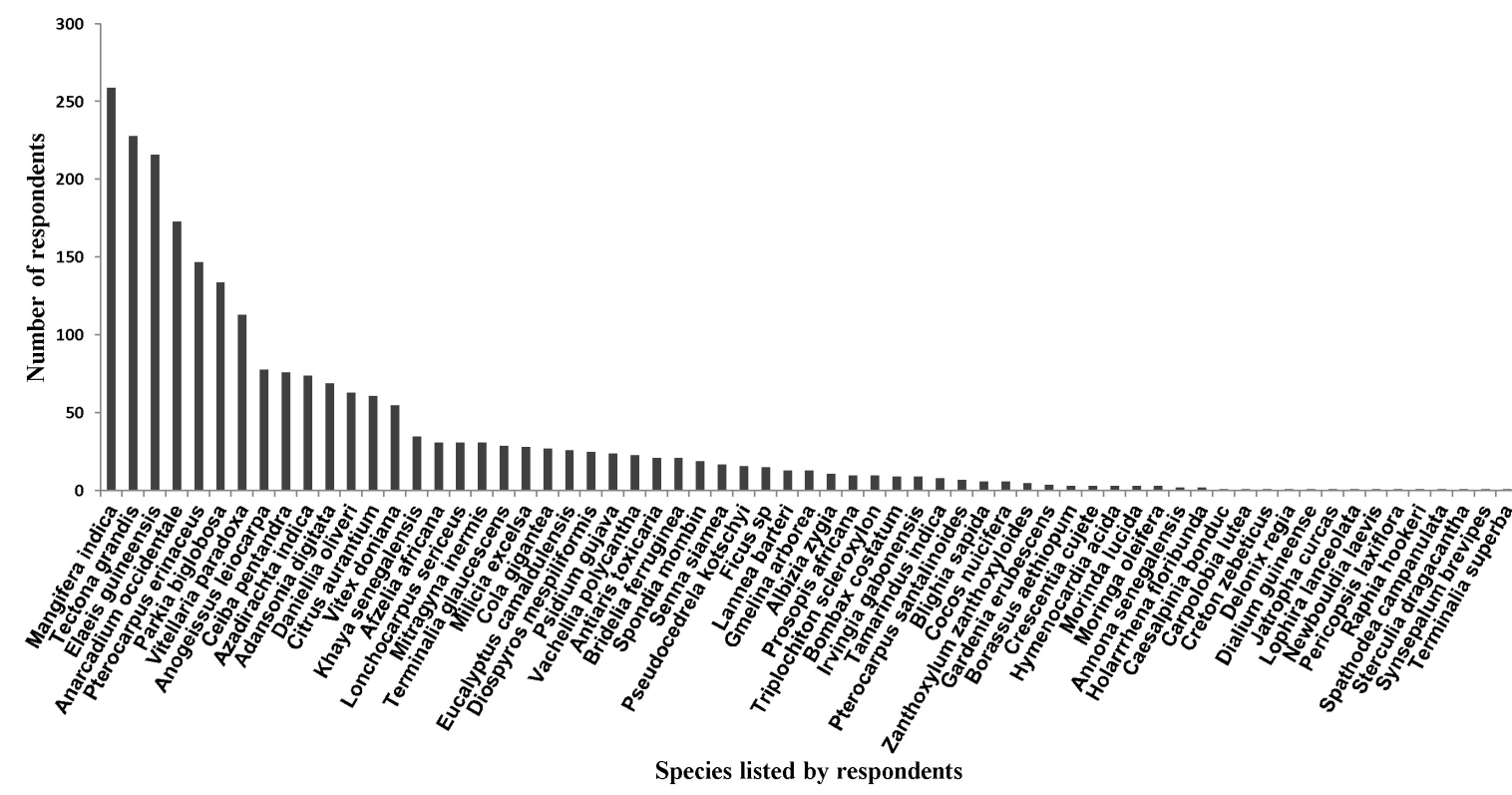

Figure 2. Woody useful species listed by the local people of the Ouémé catchment.

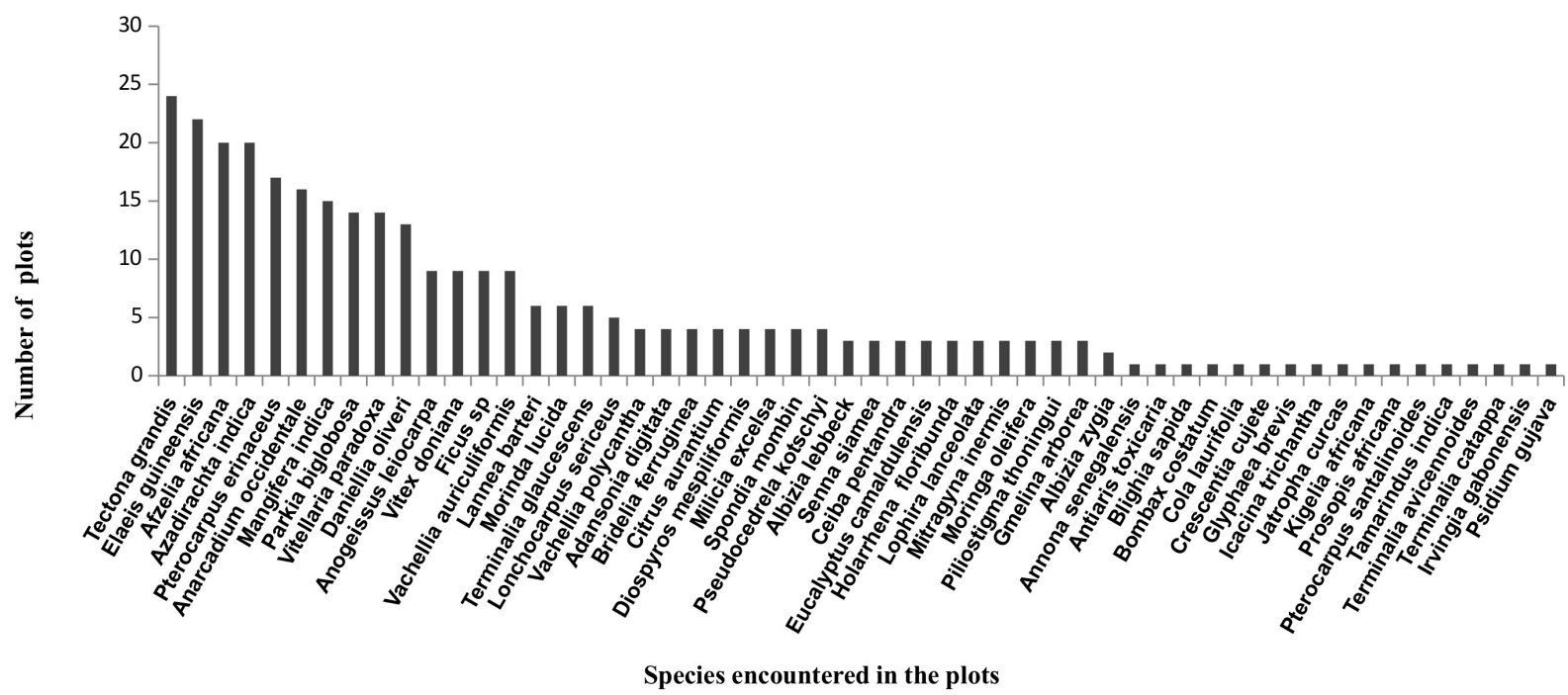

Figure 3. Woody useful species encountered in the farms.

(25\%) And root (17.5\%).

PCA conducted to describe the link between the useful woody species and UV, $\mathrm{RD}, \mathrm{RF}$ and RDo showed that the first two principal components explained $90.64 \%$ of the total variance. The first component expressed $81.95 \%$ whereas the second one expressed $8.69 \%$. The first group (Figure 6) is constituted by: Vachellia polycantha, Adansonia digitata, Albizia zygia, Annona senegalensis, Antiaris toxicaria, Blighia sapida, Bombax costatum, Bridelia ferruginea, Senna siamea, Ceiba pentandra, Citrus aurantium, Crescentia cujette, Diospyros mespiliformis, Eucalyptus, Ficus sp, Gmelina arborea, Holarrhena floribunda, Irvingia gabonensis, Jatropha curcas, Lannea barteri, Lonchocarpus leiocarpa, Lophira lanceolata, Milicia excelsa, Mitragyna inermis, Morinda lucida, Moringa oleifera, Psidium guayava, Prosopis africana, Pseudocedrala kotschyi, Pterocarpus santaliodes, Spondias mombin, 


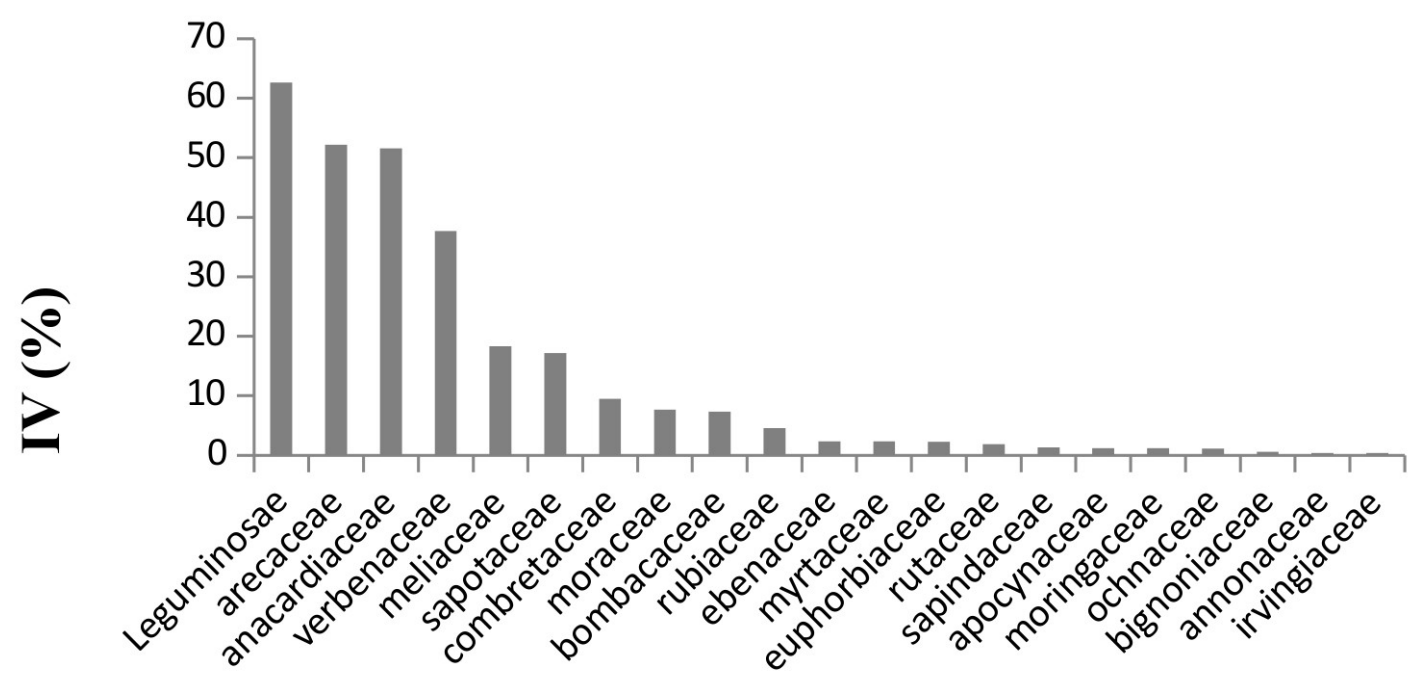

Botanical family

Figure 4. The importance value (IV) of the botanical families.

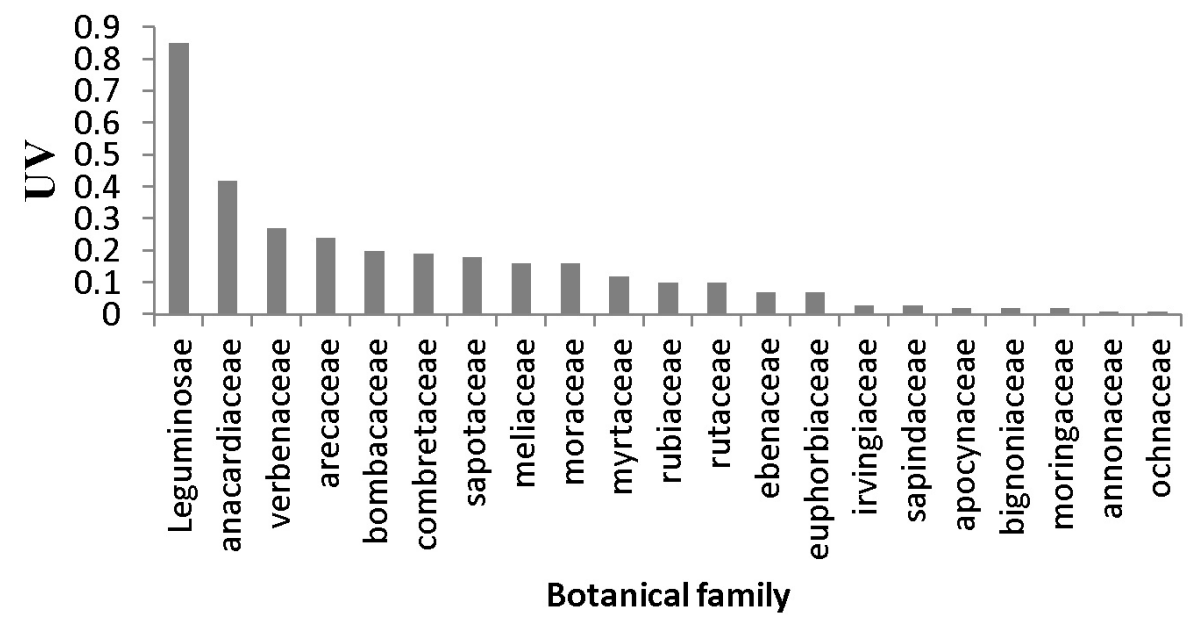

Figure 5. The use value (UV) of the botanical families.

Tamarindus indica, Terminalia glaucescens. This group is characterized by low values of UV, $\mathrm{RD}, \mathrm{RF}$ and RDo. The species with the highest correlation with the principal components were projected in the figure. The second group, including the following species Elaeis guineensis, Afzelia africana, Anacardium occidentale, Anogeissus leiocarpa, Azadirachta indica, Daniellia oliveri, Mangifera indica, Parkia biglobosa, Pterocarpus erinenceus, Tectona grandis, Vitellaria paradoxa, Vitex doniana is characterized by high values of UV, RD, RF and RDo.

\section{Local priorities for the conservation of woody species}

The Table 2 presents the species and their conservation priority scores. The top ten species that should be conserved in 


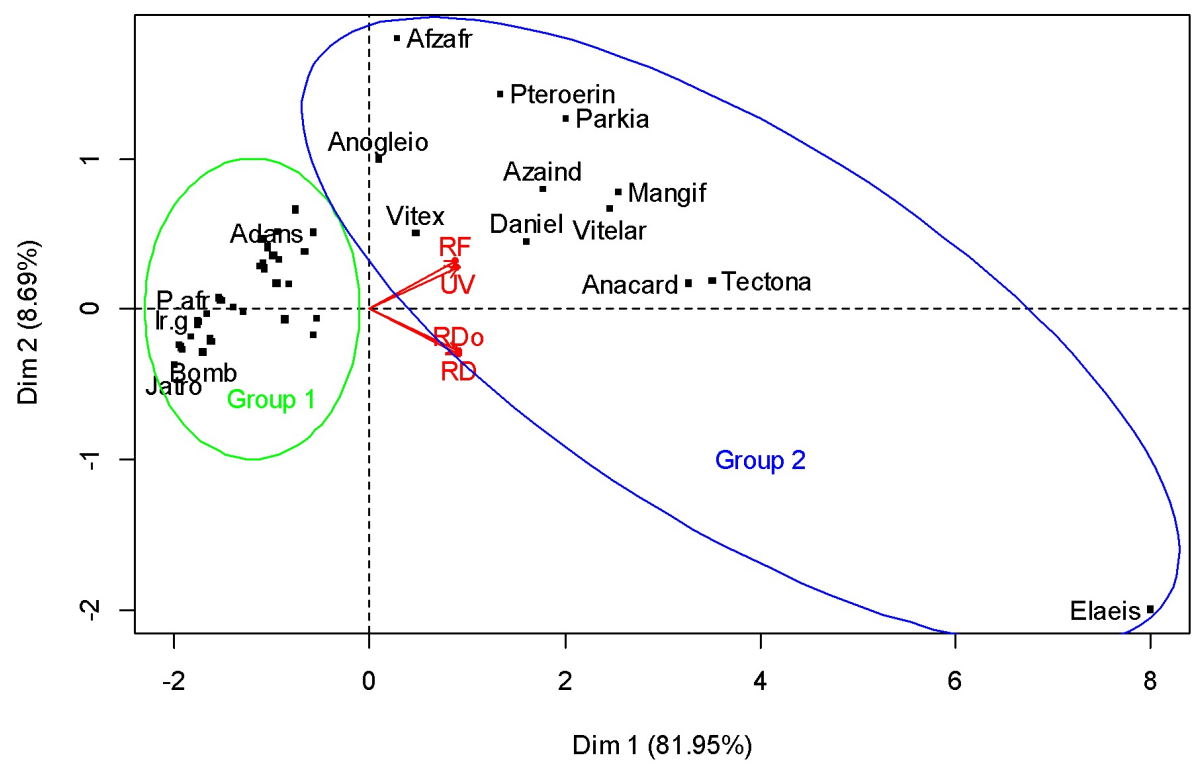

Figure 6. Principal component analysis of 45 useful woody species cited by the informants of the Ouémé catchment in Benin (West Africa).

UV: use value; RDo: relative dominance; RF: relative frequency; RD: relative density; Adans- Adansonia digitata; Bomb-Bombax costatum; I.g- Irvingia gabonensis; Jatro- Jatropha curcas; P.afr- Prosopis africana; Elaeis- Elaeis guineensis ; Afzafr- Afzelia africana; AnacardAnacardium occidentale; Anogleio- Anogeissus leiocarpa; Azaind- Azadirata indica; Daniel- Daniellia oliveri; Mangif- Mangifera indica; ParkiaParkia biglobossa; Pteroerin- Pterocarpus erinenceus; Tectona- Tectona grandis; Vitelar- Vitellaria paradoxa; Vitex- Vitex doniana

priority (based on the conservation index) are: Adansonia digitata, Parkia biglobosa, Pterocarpus erinaceus, Milicia excelsa, Irvingia gabonensis, Tamarindus indica, Vitex doniana, Prosopis africana, Diospyros mespiliformis and Pterocarpus santalinoides. These species are grouped into six families, the Leguminosae is the most represented (six species), and the other families (Bombacaceae, Moraceae, Irvingiaceae, Verbenaceae and Ebenaceae) have one species each. Among these ten species, Adansonia digitata, the most priority, is considered as vulnerable in Benin while Pterocarpus erinaceus, Milicia excelsa are endangered (Table 2). Moreover, these ten species have at least four use categories. Parkia biglobosa and Pterocarpus erinaceus demonstrated the largest use-versatility because they are used by the informants in all cited use categories.

\section{Discussion}

\section{Species richness}

The first assumption of our study stipulated that the local people of Ouémé catchment carry on maintain of biodiversity of useful woody species in their farms despite the increased threat. This assumption is accepted. Indeed, a total of 45 useful woody species were used by the local people and were available in the traditional agroforestry systems. The high number of Indigenous species confirms their importance to the local people who rely on them to improve their livelihood (Assogbadjo et al. 2012). Among the 45 species, seven were exotics: $E$. guineensis, $M$. indica, $A$. occidentale, E. camaldulensis, G. arborea, C. aurantium and $T$. grandis. These seven species and some native species were grown by the 


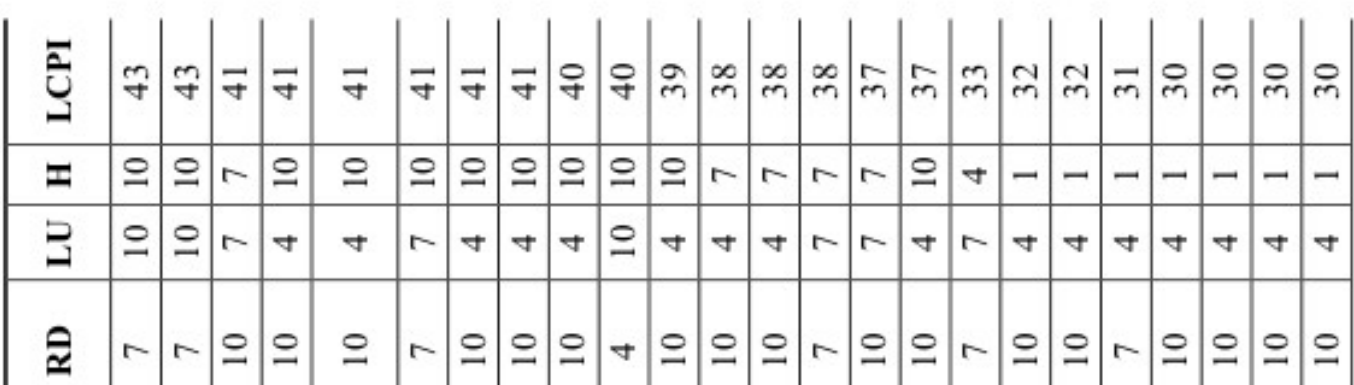

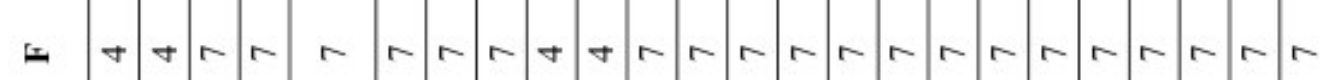

는 $ง$ ป

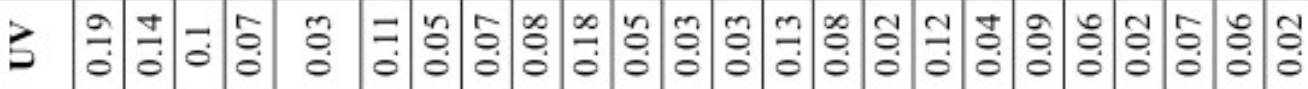

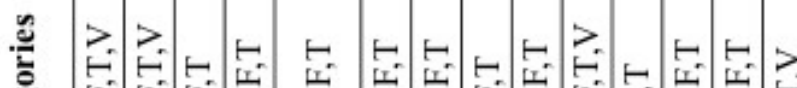

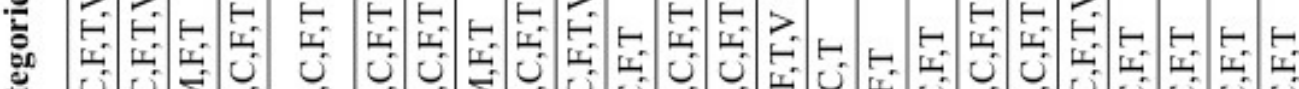
है

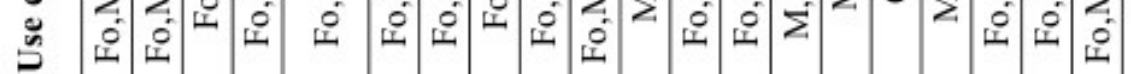

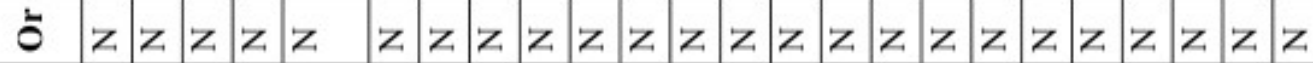

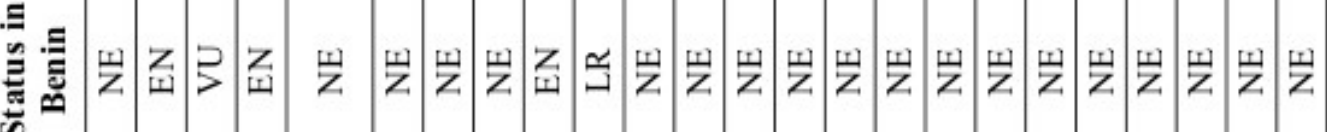

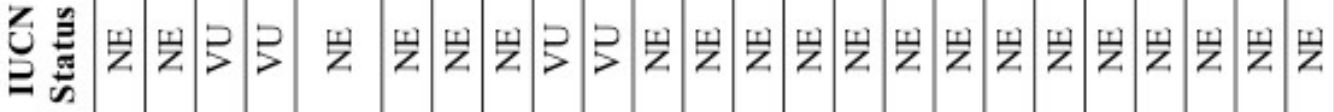

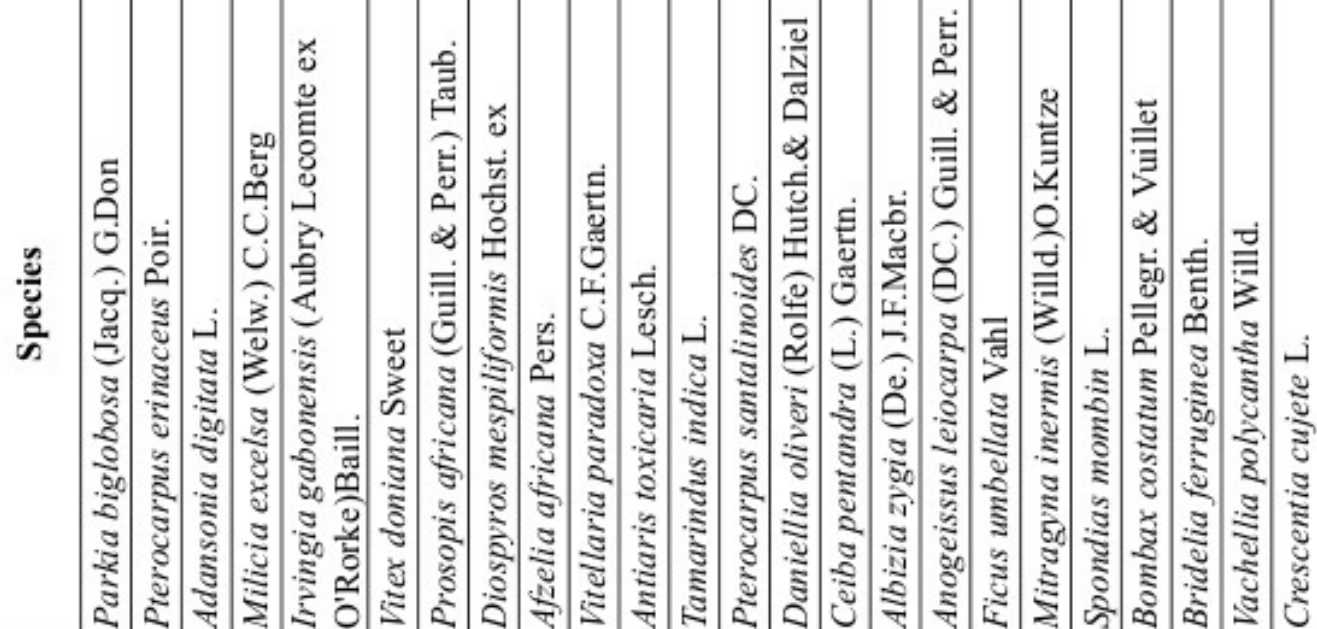

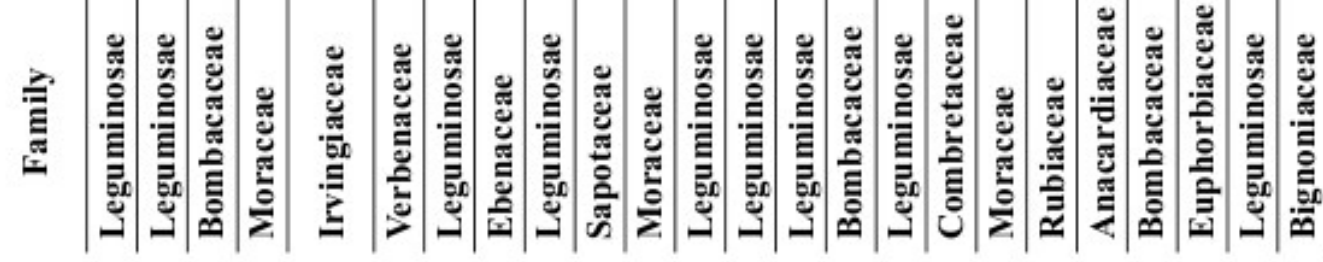




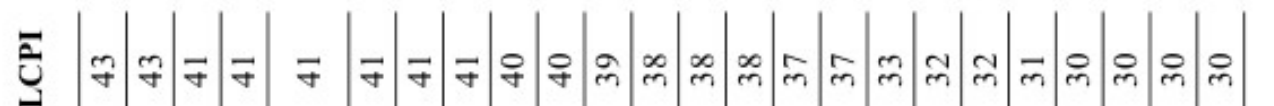

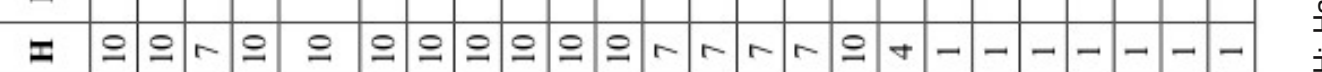

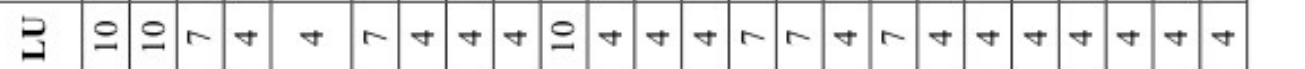

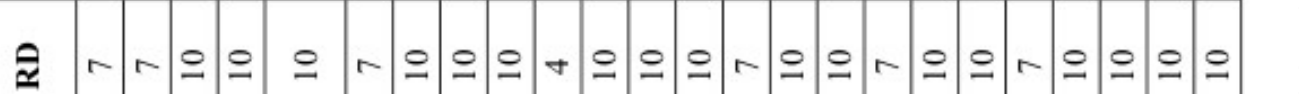

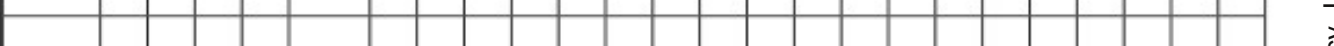

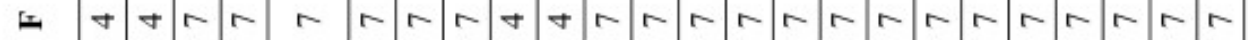

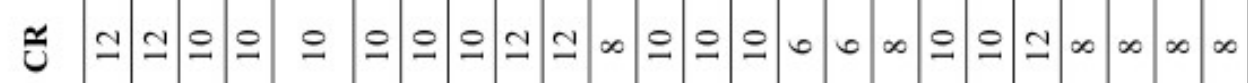

3 ப)

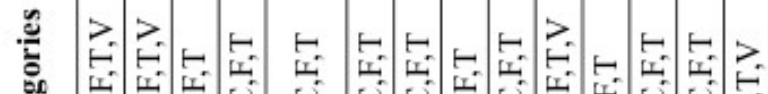

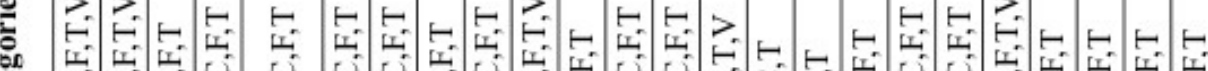

है

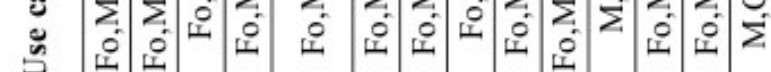

ప z z z z z z z z z z z z z z z z z z z z z z z z z z z z z z z z

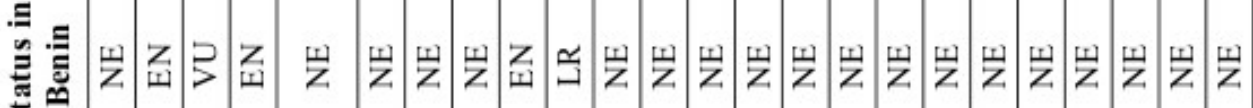

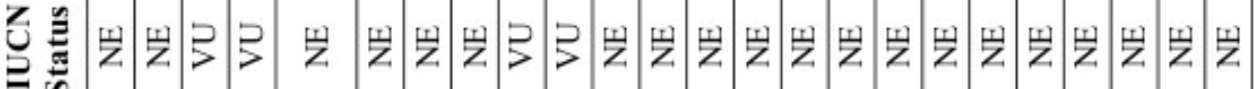


local people themselves in their fields. The seedlings of the other species come from natural regeneration and were protected in the fields. The same result had been obtained by Ouinsavi and Sokpon (2008) and Assogbadjo et al. (2012) who revealed that traditional agroforestry practices support biodiversity through in situ conservation of Indigenous tree species. Compared with previous studies, the species richness of Ouémé catchment is relatively low (90 useful woody species were mentioned in sub-sahel of Burkina Faso (Sop et al. 2012); 48 useful woody plants reported in the municipality of Planaltina in Brazil (Tunholi et al. 2013). However, the species richness found in this study is higher than the ones obtained by Lucena et al. (2007) in Caatinga (Northeastern Brazil) and Vodouhê et al. (2009) within traditional agroforestry parkland systems around the Pendjari Biosphere Reserve reporting respectively 30 and 21 useful plants. These differences may be explained by several factors such as anthropogenic pressures and environmental traits of the study areas (Adomou et al. 2006).

\section{Ethnobotanical and ecological parameters}

The second assumption of the study is also accepted. Indeed, the local people use the woody species for multiple purposes and have grouped them into six use categories. The majority of the woody species were concentrated in the categories of medicine, construction, fuel, technology and food in a decreasing order. All the species were used in at least two categories except J. curcas which is only used as medicine. Among all the species investigated, $A$. indica, S. monbin, $E$. guineensis, $P$. biglobosa, $P$. erinaceus and $V$. paradoxa stood out as the most versatile and present in all use categories. The use of the plants for medicinal purposes is very common in the Ouémé catchment area. Several parts such as bark, leaf and root are used to treat a wide range of diseases like malaria, diarrhoea, fever and anemia. This finding is consistent with previous studies showing how in Africa local people depend on medicinal plants for daily health care (Cheikhyoussef et al. 2011; Sop et al. 2012). Many species of medicinal use are also used for fuel, construction and technology. Oliveira et al. (2007) studying the woody medicinal species in Caatinga vegetation (in Brazil) observed that the plants of medicinal use usually had multipurposes, especially associated with their wood. Moreover, in the Ouémé catchment area the use of the woody species in technology is mainly focused in making pirogue. In this area all the households living near to the Ouémé river have a pirogue.

The use value technique is widely acknowledged as an objective and reliable tool to quantify the relative importance (UV) of a plant species to a community (Sop et al. 2012), as it is simultaneously based on the number of uses that are linked to the plant and the number of informants that mention it (Phillips et al. 1994). The results from PCA (Figure 6) showed that the 12 species having the highest use values also had the highest importance value (IV) through its components (RF, RD and RDo). These species were most representative in terms of number of individuals (from 31 to 259 individual plants) and represented authentic multipurpose plants that render a large number of services to local communities in Ouémé catchment, in particular during the dry season. This output proves that the relative importance of these 12 species is positively correlated to the number of uses, supporting the "apparency hypothesis" that 
the use of a species might be related to its conspicuousness (Trindade et al. 2015).

\section{Conservation priorities}

The assumption that the species that are the most used are the most priorities for conservation is not totally accepted. In fact, from the 12 most used species (group 2 of Figure 6), only five (A. africana, $P$. biglobosa, $P$. erinaceus, $V$. paradoxa and $V$. doniana) appeared in the top ten priority species for conservation. Moreover, the other seven species appeared in the less priority species for conservation. This could suggest that the most important species in terms of use values and number of individuals were not necessarily considered of high priority for conservation. Four species can illustrate this situation: $A$. occidentale, E. guineensis, M. indica, A. occidentale and $T$. grandis. These species although important in terms of use values were not considered of priority for conservation. The reason must be the fact that these species are relatively common in the catchment and have a relative rapid growth but also they have a high regeneration rate. These species are planted by the peasants themselves in the farms. They do not represent any sign of declining.

Eyog Matig et al. (2002) have ranked the importance of multipurpose species from the perspective of rural people in Benin. Their outcome has ranked ten species, $A$. occidentale, V. paradoxa, P. biglobossa, I. gabonensis, $D$. guineense, $P$. butyracea, $A$. altilis, C. albidum, $A$. digitata and $T$. indica, being perceived as the most important species to the rural communities to be conserved in Benin. Four of the ten priority species recorded in this study, A. digitata, P. biglobosa, I. gabonensis, V. paradoxa, are consistent with the finding of Eyog Matig et al. (2002). Moreover, from 12 species having high UV and IV (Group 2 of
Figure 6), only two, P. biglobosa and V. doniana, appeared among the ten priority species for conservation.

A. digitata, P. biglobosa, I. gabonensis, V. paradoxa and $V$. doniana considered as priority for conservation in the present study are also considered as priority in several other West and Central African countries (Faye et al. 2010; Sop et al. 2012). The essential criteria that lead to the choice of these species are the nutritional and socioeconomic values of their fruits and seeds to local people (Nikiema 2005). Another reason that can support the choice of $A$. digitata is that this species is considered sacred because of its magical/spiritual role. However, the vulnerability of these species is of major concern (Sop et al. 2012). They are under threat, facing population declines mainly due to regeneration failure, population aging, drought and human pressure. The collection and mutilations of organs of these species are common in the study area and could have a negative effect on young trees especially during the dry season when water content in the soil decreases (Lokonon et al. 2013). Moreover, the fruits harvesting and seeds collection could negatively affect regeneration density since embryos of seeds are often damaged. Contrary to the previous species from which the choice is related to the fruits and seeds, $P$. erinaceus, $M$. excelsa, $P$. africana, $D$. mespiliformis and $P$. santalinoides are considered priority due to their timber resources. They are most used for fuel, construction and technological purposes. Their timbers are heavily extracted for charcoal and pirogue production and frequently commercialized.

\section{Limits of prioritization approach}

The failure to differentiate between effective and potential use may overestimate 
the pressure on the species. In order to address this problem, it may be useful to calculate the conservation index by distinguishing the actual situation from the potential situation. The potential situation is a situation in which the species frequently required and used may be replaced by those rarely or never used in the past. According to Brehm et al. (2010), species prioritization for conservation is a dynamic process and for this reason, the list of ranked species for conservation must be regularly revised. Moreover, many species present equal or very close values of LCPI. In the case of equal values of LCPI, what is the tiebreaking criterion? This situation could be solved with the addition of other important variables in the calculation of LCPI, such as the differentiation between commercialized and non-commercialized species.

\section{Conclusions and implications for conservation}

This research has highlighted how the traditional agroforestry system in Ouémé catchment remains an important useful woody species pool for local people. There is diversity in the use of the species. Some species are preferentially used for their fruits and seeds while the others are most used for their timbers. The outcomes of the study meet the idea that there is positive relationship between the availability of a species and its use by the local people. This finding is reinforced by the fact that people tend to preserve in the agroforestry systems the species they prefer to use. The woody species are used in a wide range of categories, indicating the close links between livelihoods and natural resources in the area. This study shows that, the richness of knowledge and management techniques accumulated by the local people can be particularly valuable for developing strategies for conservation of plant resources. Supplementing scientific data with local and traditional knowledge can broaden the information base needed for informed decision-making regarding sustainable resource management. This is especially the case when other historical ecological information is unavailable. The prioritization method has ranked top ten species for conservation: $P$. biglobosa, $P$. erinaceus, A. digitata, M. excelsa, I. gabonensis, $V$. doniana, $P$. africana, $D$. mespiliformis, $A$. africana and $V$. paradoxa. Most of these priority species are slow to regenerate and facing a rapid decline in their natural populations outside the agroforestry systems due to their intensive use. Moreover, they are still undomesticated or semi-domesticated. The domestication of these species is necessary to protect natural stands and to provide a sustainable source of food, medicine and income to local population. In order to make the domestication process more effective, local farmers' preferences should be taken into account. Through the domestication process, new varieties of plants with shorter life cycles, which are able to persist during the drought, should be selected.

\section{Acknowledgement}

This work was supportd by the grant from International Foundation for the Science (IFS). We thank this institution and its donors. Thanks are also due to the local people for their generous hospitality. We are also grateful to the reviewers for their relevant comments. 


\section{REFERENCES}

Adomou AC, Sinsin B, van der Maesen LJG (2006) Phytosociological and chorological approaches to phytogeography: a study at meso-scale in Benin. Systematics and Geography of Plants 76:155-178

Akoègninou $A$, van der Burg $W J$, van der Maesen LJG (2006) Flore analytique du Bénin. Backhuys Publishers, Wageningen, Netherlands.

Albuquerque UP, Sousa TAA, Ramos MA, Nascimento VT, Lucena RFP, Monteiro JM, Alencar NL, Lima AE (2009) How ethnobotany can aid biodiversity conservation: Reflections on investigations in the semi-arid region of NE-Brazil. Biodiversity and Conservation 18:127-150

Araújo EL, Ferraz EMN (2014) Analysis of vegetation in ethnobotanical studies. In: Albuquerque UP, Lucena RFP, Cunha LVFC, Alves, RRN (eds.) Methods and Techniques in Ethnobiology and Ethnoecology, Springer Protocols Handbooks, pp. 141-159

Arbonnier M (2000) Arbres, arbustes et lianes des zones sèches d'Afrique de I'Ouest. CIRAD-MNHN, Versailles, France

Assogbadjo AE, Kyndt T, Sinsin B, Gheysen G, Van Damme P (2006) Patterns of genetic and morphometric diversity in baobab (Adansonia digitata) populations across different climatic zones of Benin (West Africa). Annals of Botany 97:819-830

Assogbadjo AE, Glèlè Kakaï $R$, Vodouhê FG, Djagoun CAMS, Codjia JTC, Sinsin B (2012) Biodiversity and socioeconomic factors supporting farmers' choice of wild edible trees in the agroforestry systems of Benin (West Africa). Forest Policy and Economics 14:41-49
Asuzu IU, Harvey AL (2003) The antisnake venom activities of Parkia biglobosa (Mimosaceae) stem bark extract. Toxicon 42:763-768

Brehm JM, Maxted N, Martins-Loução MA, Ford-Lloyd BV (2010) New approaches for establishing conservation priorities for socio-economically important plant species. Biodiversity and Conservation 19(9):2715-2740

Cheikhyoussef A, Shapi M, Matengu K, Ashekele HM (2011) Ethnobotanical study of indigenous knowledge on medicinal plant use by traditional healers in Oshikoto Region, Namibia. Journal of Ethnobiology and Ethnomedicine 7:10

Cuni Sanchez A, Haq N, Assogbadjo A (2010) Variation in baobab (Adansonia digitata L.) leaf morphology and its relation to drought tolerance. Genetic Resources and Crop Evolution 57:17-25

Dagnelie P (1998) Statistiques théoriques et appliquées. De Boeck et Larcier, Brussels, Belgique

De Smedt S, Alaerts K, Kouyaté AM, Van Damme P, Potters G Samson R (2011) Phenotypic variation of baobab (Adansonia digitata L.) fruit traits in Mali. Agroforestry Systems 82:87-97

Egbe EA, Tabot PT, Fonge BA (2012) Ethnobotany and prioritization of some selected tree species in southwestern Cameroon. Ethnobotany Research and Applications 10:235-246

Eloy L (2008) Dynamiques et adaptation des systèmes agroforestiers périurbains dans le nord-ouest Amazonien. Bois et Forêts Tropicales 296(2):45-54

Eyog Matig O, Gaoue OG, Dossou B (2002) Réseau «Espèces ligneuses alimentaires». Compte rendu de la 
première activité du réseau tenue 11-13 décembre 2000 au CNSF, Ouagadougou, Burkina Faso. Institut International des Ressources Phylogénétiques, Rome

Fandohan B, Assogbadjo AE, Glèlè Kakaï R, Kyndt T, De Caluwe E, Codjia JTC, Sinsin B (2010) Women's traditional knowledge, use value and the contribution of tamarind (Tamarindus indica L.) to rural households' cash income. Economic Botany 64, 248-259

Faye MD, Weber JC, Mounkoro B, Dakouo JM (2010) Contribution of parkland trees to farmers' livelihoods: a case study from Mali. Development in Practice 20:428-434

Galeano G (2000) Forest use at the Pacific coast of Chocó, Colômbia: A quantitative approach. Economic Botany 54(3):358-376

Hiepe C (2008) Soil degradation by water erosion in a sub-humid West-African catchment, a modelling approach considering land use and climate change in Benin. PhD thesis, University of Bonn, Germany

Hiepe C, Diekkrüger B (2006) Soil erosion in the Upper Ouémé Catchment (Benin) considering land use and climate change a modelling approach. Conference on International Agricultural Research for Development, October 11-13, University of Bonn, Germany

Husson F, Josse J, Le S, Mazet J (2014) FactoMineR: Multivariate Exploratory Data Analysis and Data Mining with $\mathbf{R}$. R package version 1.26. https://CRAN.Rproject.org/package=FactoMineR.

Kell SP, Knüpffer H, Jury SL, Ford-Lloyd BV, Maxted N (2008) Crops and wild relatives of the Euro-Mediterranean region: making and using a conservation catalogue. In: Maxted N, Ford-Lloyd BV, Kell SP, Iriondo J, Dulloo E, Turok J (eds) Crop wild relative conservation and use. CAB International, Wallingford, pp. 69-109

Keyzer MA, Sonneveld BGJS, Pande S (2007) The impact of climate change on crop production and health in West Africa: an assessment for the Oueme River Basin in Benin. [http://www.sow.vu.nl/pdf/Rivertwin.pdf]

Accessed January 2017

Kpadonou RAB, Adégbola PY, Tovignan SD (2012) Local knowledge and adaptation to climate change in ouémé valley, Benin. African Crop Science Journal 20:181-192

Kyndt T, Assogbadjo AE, Hardy OJ, Glèlè Kakaï R, Sinsin B, Damme PV, Gheysen G (2009) Spatial genetic structuring of baobab (Adansonia digitata, Malvaceae) in the traditional agroforestry systems of West Africa. American Journal of Botany 96(5):950-957

Lokonon EB, Bonou WN, Kassa B, Azihou AF, Assogbadjo AE, Glèlè Kakaï R (2013) Structural and ethnobotanical characterization of velvet tamarind (Dialium guineense willd), a multipurpose tree species. Agronomie Africaine 25(2):121-131

Lucena RFP, Araújo EL, Albuquerque UP (2007) Does the local availability of woody Caatinga plants (Northeastern Brazil) explain their use value? Economic Botany 61(4):347-361

Lucena RFP, Nascimento VT, Araújo EL, Albuquerque UP (2008) Local uses of native plants in na area of Caatinga vegetation (Pernambuco, NE Brazil). Ethnobotany Research and Applications 6:313

Lykke AM (2000) Local perceptions of vegetation change and priorities for conservation of woody-savanna vegetation in Senegal. Journal of 
Environmental Management 59:107-120

Nikiema A (2005) Agroforestry Parkland Species Diversity: Uses and Management in Semi-Arid West Africa (Burkina Faso). $\mathrm{PhD}$ thesis, Wageningen University, Netherlands

Nouaïm R, Echairi A, Kaaya M, Chaussod R (2007) Contribution à la domestication de l'arganier pour la production d'huile. Cahiers Agricultures 16:199-204

Oke DO, Jamala GY (2013) Traditional agroforestry practices and woody species conservation in the derived savanna ecosystem of Adamawa state, Nigeria. Biodiversity Journal 4(3):427-434

Oliveira RLC, Lins Neto EMF, Araújo EL, Albuquerque UP (2007) Conservation priorities and population structure of woody medicinal plants in an area of Caatinga vegetation (Pernambuco state, NE Brazil). Environmental Monitoring and Assessment 132:189-206

Omafuvbe BO, Falade OS, Osuntogun BA Adewusi SRA (2004) Chemical and biochemical changes in African locus bean (Parkia biglobosa) and Melon (Citrus vulgaris) seeds during fermentation to condiments. Pakistan journal of nutrition $3: 140-145$

Ouinsavi C, Sokpon N (2008) Traditional agroforestry systems as tools for conservation of genetic resources of Milicia excelsa Welw. C.C. Berg in Benin. Agroforestry Systems 74:17-26

Phillips O, Gentry AH (1993) The useful plants of Tambopata, Peru: I. Statistical hypotheses tests with a new quantitative technique. Economic Botany 47:15-32

Phillips O, Gentry AH, Reynel C, Wilkin P, Galvez-Durand C (1994) Quantitative ethnobotany and Amazonian conservation. Conservation Biology 8:225248

Rossato SC, Leitão-Filho HF, Begossi A (1999) Ethnobotany of Caiçaras of the Atlantic Forest Coast (Brazil). Economic Botany 53:387-395

Sina S (2006) Reproduction et diversité génétique chez le Parkia biglobosa (Jacq.) G.Don. PhD Thesis, Université de Wageningen, Pays-Bas

Sintondji L (2005) Modelling the rainfallrunoff process in the Upper Ouémé catchment (Térou in Benin Republic) in a context of global change: extrapolation from the local to the regional scale. PhD Thesis, University of Bonn, Germany

Sop TK, Oldeland J, Bognounou F, Schmiedel U, Thiombiano A (2012) Ethnobotanical knowledge and valuation of woody plants species: a comparative analysis of three ethnic groups from the sub-Sahel of Burkina Faso. Environment, Development and Sustainability 14:627-649

Stagegaard J, Sørensen M, Kvist LP (2002) Estimations of the importance of plant resources extracted by inhabitants of the Peruvian Amazon flood plains. Urban e Fischer Verlag 5:103-122

Teklehaimanot Z (2004) Exploiting the potential of indigenous agroforestry trees: Parkia biglobosa and Vitellaria paradoxa in sub-Saharan Africa. Agroforestry Systems 61:207-220

Trindade MRO, Jardim JG, Casas A, Guerra NM, Lucena RFP (2015) Availability and Use of Woody Plant Resources in Two Areas of Caatinga in Northeastern Brazil. Ethnobotany Research and Applications 14:313-330.

Tunholi VP, Ramos MA, Scariot A (2013) Availability and use of woody plants in an 
agrarian reform settlement in the cerrado of the state of Goiás, Brazil. Acta Botanica Brasilica 27(3):604-612

Vodouhê GF, Coulibaly O, Greene C, Sinsin $B$ (2009) Estimating the local value of non-timber forest products to Pendjari Biosphere Reserve Dwellers in Benin. Economic Botany 63:397-412

Received: 26 July 2016

Accepted: 01 February 2017

Published: 09 May 2017 